\title{
Self-employment's vulnerability to socioeconomic and working conditions: results from the Korean Working Condition Survey (2006-2014)
}

\author{
Jin-Young Min', Hye-jin Kim², Kyoug-Bok Min² \\ ${ }^{1}$ Institute of Health and Environment, Seoul National University, Seoul, Republic of Korea, ${ }^{2}$ Department of Preventive Medicine, College of Medicine, \\ Seoul National University, Seoul, Republic of Korea \\ Keywords: global health \\ https://doi.org/10.29392/joghr.3.e2019038
}

\section{Journal of Global Health Reports}

Vol. 3, 2019

\section{Background}

Self-employed professionals are responsible for the major part of the labor market. It is essential to understand the characteristics of the self-employed to promote "decent work" for this segment of workers. The current study aimed to describe the personal and work-related attributes of the self-employed group in South Korea.

\begin{abstract}
Methods
We used data from the 2006, 2010, and 2014 Korean Working Condition Survey (KWCS). For the current study, a total of 41,775 subjects included and classified them into for self-employed workers (small business owners with 0-4 employees and middle to large business owners with more than 5 employees) and workers with standard full-time employment. Socio-demographic variables included age, gender, educational attainment, income per month, and occupation. Work-related attributes included work time, weekend work, "presenteeism", and work-life balance.
\end{abstract}

\begin{abstract}
Results
The percentage of self-employed people increased to 32.78\% in 2010 and then decreased to $32.2 \%$ in 2014 to return to the same level in 2006. In comparison to middle to large business owners or workers in standard employment, small business owners were more likely to be older and male, earn lower levels of monthly income, attain lesser levels of education, and were engaged in manual and service positions. They worked longer weekday hours, worked more often on the weekends, and worked even when they were sick. Small business owners were particularly susceptible to imbalances between work and other aspects of their lives.
\end{abstract}

\section{Conclusions}

Our descriptive investigation showed that self-employed individuals, especially those heading small businesses, were more likely to be exposed to socioeconomic disadvantages and to the worst working conditions than standard waged workers.

The new global agenda pertaining to Sustainable Development Goals (SDGs) was adopted in 2015 by the 193 member states of the United Nations. The 17 specific objectives of tacking all forms of poverty, inequality, and climate change were published. Given the trends in labor markets across the world, circumstances such as economic crises, globalization, and technological advancements have facilitated the elimination of certain jobs. ${ }^{1,2}$ Hence, the private sector faces the challenge of creating job opportunities, making work prospects more precarious for individuals. ${ }^{1,2}$ The realization of the SDG blueprint, specifically goal number 8 (decent work and economic growth) is essential to eradicate social and health inequalities for working population of employed individuals. ${ }^{3}$
Employment status is probably a hallmark for attaining SDG 8. The work position affects the rights and responsibilities of employees and employers in the workplace and becomes an important social determinant for health inequalities. $^{2}$ An individual's placement at work is determined by a contract of employment, which establishes and binds the employee/employer relationship. On the other hand, selfemployment represents an "atypical" employment contract. ${ }^{4}$ Self-employed persons work for themselves as owners of a business rather than for an employer. This situation enables them to create their own working conditions, to act as independent actors in the market, and to have more autonomy and flexibility than waged employees. ${ }^{4,5}$ Nevertheless, self-employment is possibly one of the most vulnera- 
ble aspects of labor markets. The lack of social protection (ie, health insurance and pension plan) and labor regulations (ie, adequate working conditions) for formal employment are vital reasons for the self-employed to be regarded as a residual group outside of the purview of labor standards and regulation. 2,6 The aforementioned conditions present barriers to equitable health and well-being for self-employed workers, even though they benefit from high job control and satisfaction. 5,7,8 Regretfully, this type of employment has not attracted due attention from policy makers and researchers probably because of the informality of this sector and the limited data available from it. As a key driver of economic and job growth, self-employed professionals are responsible for the major part of the labor market. ${ }^{4,9}$ Thus, it is essential to understand the characteristics of the self-employed to promote "decent work" for this segment of workers.

The current study aimed to describe the personal and work-related attributes of the self-employed group in South Korea. To this end, the working population was categorized as self-employed workers (specifically, "small business selfemployed" and "middle to large business self-employed') and "workers in standard employment". Using data from the 2006, 2010, and 2014 Korean Working Condition Survey (KWCS), the socio-demographic and work-related features of the self-employed were compared, designating employees in standard employment as the reference group.

\section{METHODS}

\section{DATA COLLECTION AND PARTICIPANTS}

This study used data from the 2006, 2010, and 2014 KWCS, conducted by the Korea Occupational Safety and Health Agency. The KWCS was modeled on the European Working Conditions Survey and was translated and modified to create a Korean version that was apt for Korean culture and working conditions. ${ }^{10}$ The KWCS aimed to comprehensively articulate the working conditions of Korean workers to discover their exposure to risk factors and to ascertain the manners in which these risk factors were affected by occupation, business, or type of employment. To select a representative sample of the economically active population, the target population was the entire working populations who were over 15 years old at the time of the interview and who worked for pay or profit for at least 1 hour in the week preceding the interview. Retired and unemployed persons, home makers, and students were excluded from the survey. Eligible employment status was employee, self-employed, unpaid family-member workers, or temporarily unemployed. The sample frame was based on the National Population and Housing Census. In the first stage, census districts were selected using probability proportional to size systematic sampling, based on the number of households in the census district. Subsequently, ten households were sampled randomly within each selected census district. All the interviews were conducted face to face by trained interviewers in the respondent's own household. ${ }^{11}$

For the current study, we first confirmed the self- employed and wage employees at each phase of the KWCS (2006, 2010, and 2014). Once the self-employed participants were ascertained, individuals who were engaged in skilled agricultural occupations, forestry, and fisheries were excluded because of certain distinctive features such as working in family farms, seasonal activities, or excess labor supply in relatively short periods. The screened list of self-employed workers were classified into small business owners who employed fewer than 5 employees and middle to large business owners who employed more than 5 employees. In the case of wage employees, workers in nonstandard work arrangements (ie, part-time and temporary agency workers) were excluded, and only those with standard full-time employment were included in the population for this study. Workers with non-standard employment are considered precarious workers and are associated with reduced occupational health and safety and poor working conditions. ${ }^{1,2}$ Thus, they cannot be incorporated in the same category as workers in standard employment. Finally, the study participants were described in the following manner: The first wave of the KWCS was conducted in 2006 with a total of 10,043 participants, wherein 7,416 participants (2,328 self-employed persons and 5,088 workers in standard employment) were included for the current study. In 2010, a total of 10,019 face-to-face interviews were conducted and finally included 6619 workers with 2,236 self-employed individuals and 4,383 employees in standard employment. In 2014, a total of 50,007 workers were interviewed, and 27740 participants with 16,821 self-employed personnel and 22,171 workers in standard employment were identified.

\section{QUESTIONNAIRE}

The interview questions were designed to provide detailed information on the demographic and socioeconomic characteristics and working conditions of Korean workers. Demographic and socioeconomic variables included age (20-29, 30-39, 40-49, or 50-59), gender (male or female), and educational attainment (elementary or less, middle to high school, or college or more). The income level was divided into four categories (US\$): <US\$1000, US\$ 1000-US\$ 1999 , US\$ 2000-US\$2999, and $\geqslant$ US\$ 3000. Occupational status encompassed the eight classes based on the Korean Standard Classification of Occupations with the exclusion of skilled agricultural workers, those engaged in forestry, people working in fisheries, and military personnel. The respondents were classified further into three groups: white collar (senior manager, professional/technical expertise, clerks), blue collar (craft and related trade workers, equipment/machine operators, and assembly hands), and pink collar (service and sales personnel).

Work-related characteristics included work durations, weekend work, "presenteeism", and work-life balance. Work duration was calculated on a weekly basis and was treated as continuous time. The classification of working unduly long hours computed with 52 hours per week as the cut-off point, and two categories ( $\geqslant 52$ vs. <52) were established. Weekend work was ascertained by the question, "how many times a month do you work on Sundays/Saturdays?". The term "presenteeism” signified "working while sick" and was investigated from yes/no question, "'Over the past 12 months did you work when you were sick?". Work-life balance was ascertained form the participants' 


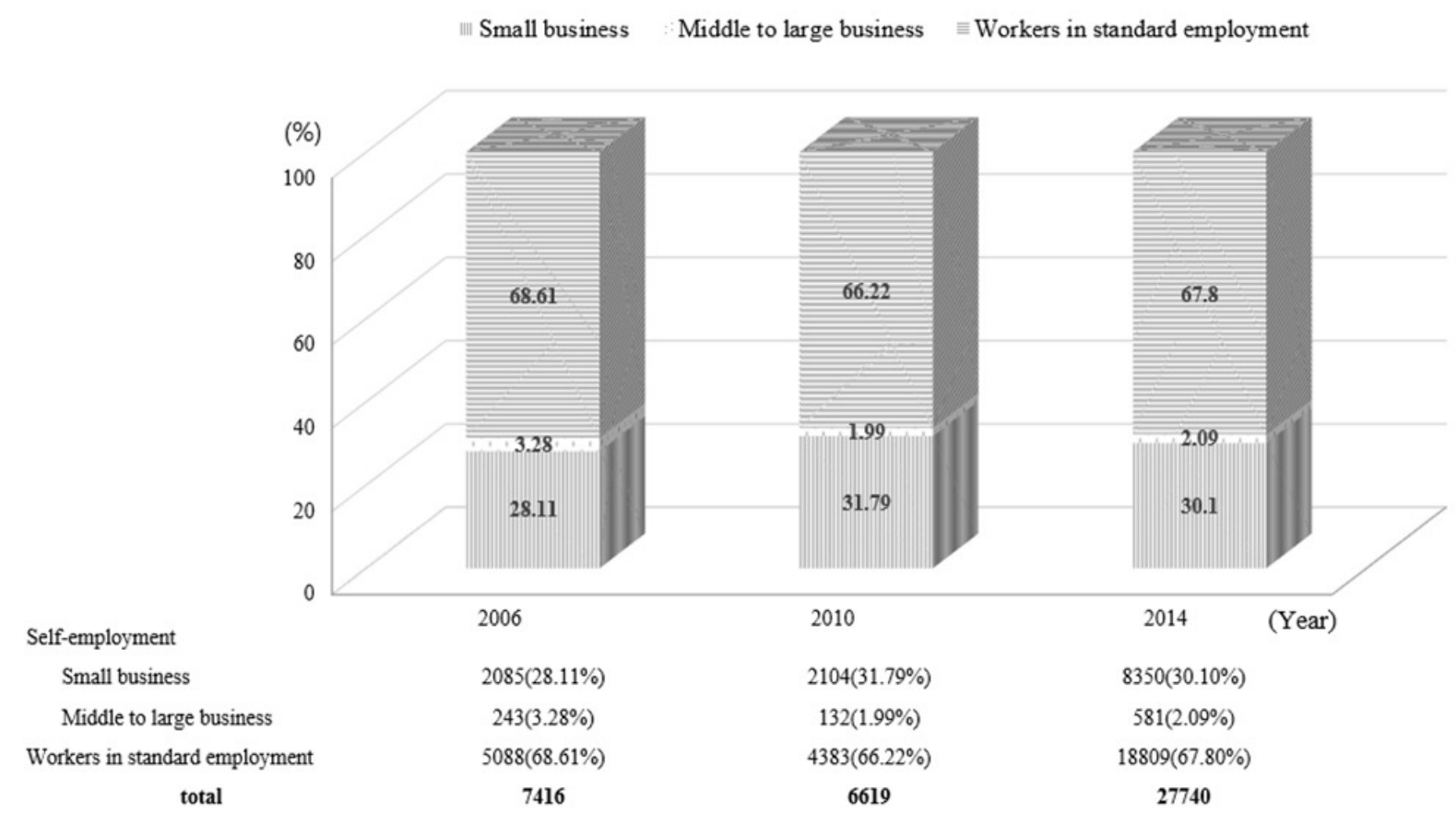

Figure 1. Distribution of the working population across the study years of 2006, 2010, and 2014.

responses to questions that asked whether their weekly work durations were suited to their family or private lives. The participants were given the choice of the following answers: "very well”, "well”, "not well”, and "not at all”. Workers who answered "very well" and "well” were defined as people who had achieved work-life balance and those who responded "not well" and "not at all" were categorized as leading an unbalanced life regarding their work.

\section{STATISTICAL ANALYSIS}

To compare demographic and socioeconomic characteristics and the working conditions of the study population among the three working groups (small business self-employed, middle to large business self-employed, and workers with standard employment), the mean and SE for continuous variables and the numbers and percentage for categorical variables were calculated. Tests of statistical differences among the three working population were based on ANOVA and $\chi^{2}$ statistics. The SAS 9.2 software (SAS Institute, Cary, $\mathrm{NC}$, USA) was used to perform all of the analyses.

\section{RESULTS}

The working population rates in 2006 were $31.39 \%$ for selfemployed persons and $68.61 \%$ for workers in standard employment (Figure 1). Subsequently, the percentage of selfemployed people increased to $32.78 \%$ in 2010 and then decreased to $32.2 \%$ in 2014 to return to the same level in 2006. Small business owners amounted to $90 \%$ of the self-employed individuals in 2006; but their proportions increased to about $94 \%$ in both 2010 and 2014 . The percentage of standard employees decreased to $66.22 \%$ in 2010 and increased again to $67.8 \%$ in 2014 .
Self-employed workers in both small business and middle to large business were more likely to be older than workers in standard employment were (Figure 2). In 2006, selfemployed individuals were mostly in the 40-49 age group. As the years progressed, the numbers for people in their 50 s increased, signifying that entrepreneurs were getting older. The rate of male workers engaging in self-employed and standard employment was higher than those of female workers across the years, in every phase of the KWCS. The percentage of female middle to large business owners was particularly low $(18.52 \%$ in $2006 ; 17.42 \%$ in 2010 ; and $21 \%$ in 2014). However, the proportion of female workers gradually increased with the years, and in 2014 female workers self-employed in small businesses and in standard employment reached almost half.

Although the percentage of workers with the lowest monthly income (<UUS\$ 1000) decreased with the passing of the years, the lowest income ( $<$ US\$ 1000) was found to be most prevalent for those who were self-employed in small businesses: $21.58 \%$ in $2006,11.88 \%$ in 2010 , and $4.68 \%$ in 2014 (Table 1). Middle to large business owners were reported to be the high earners among all the types of workers who were examined. Around $75 \%$ of the workers in standard employment earned monthly wages that ranged between US\$ 1000 and US\$ 2999. In terms of educational attainment, more than half of the middle to large business owners and the workers in standard employed workers held college or post-graduate degrees. Conversely, small business owners contributed the highest proportion of middle to high school graduates: $65.52 \%$ in 2006, 65.11\% in 2010, and 63.87\% in 2014. Similarly, more than half the self-employed personnel of middle to large business enterprises and workers in standard employments were likely to be engaged in white collar jobs, while self-employed small business personnel 

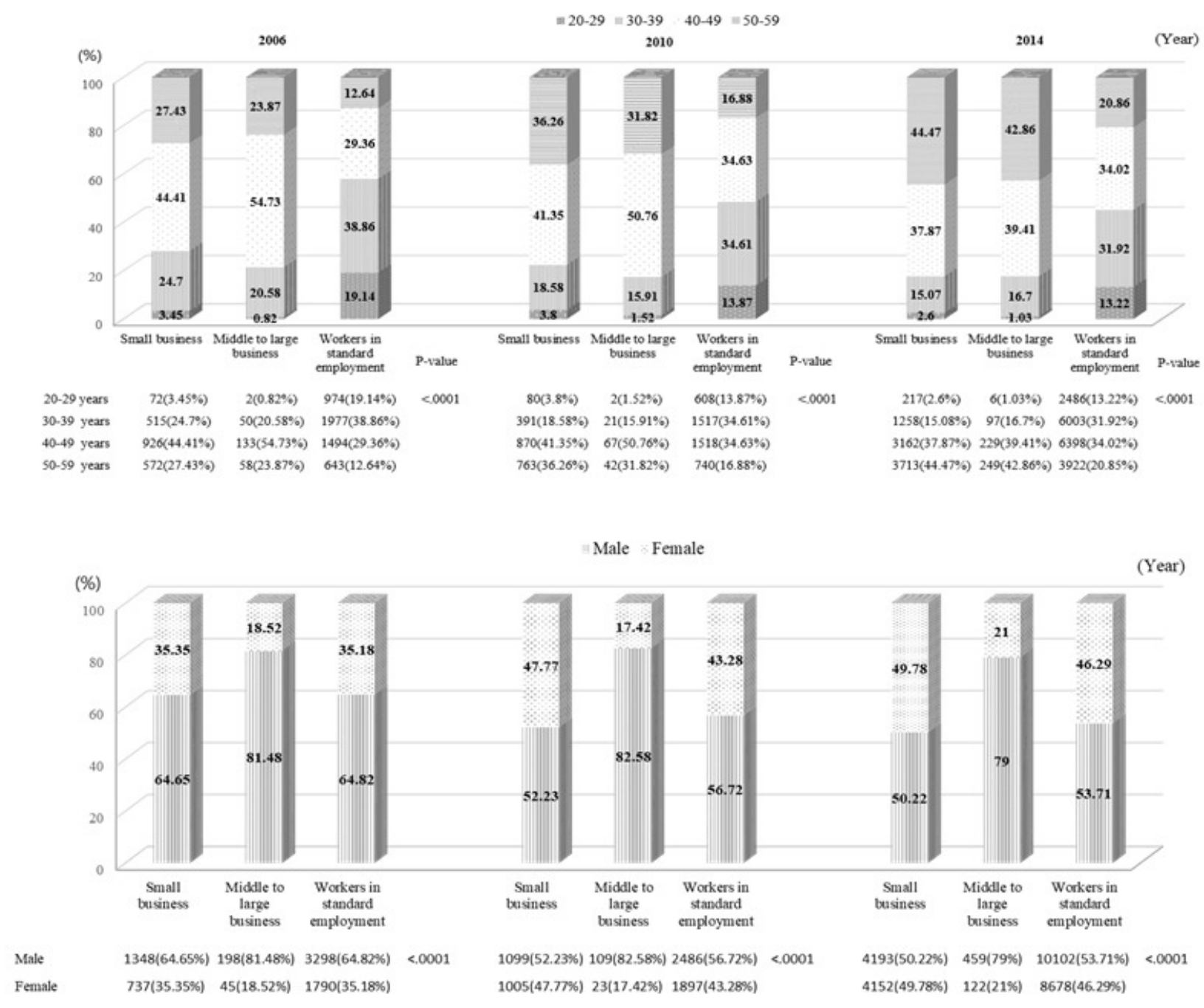

Figure 2. Distribution of age and gender for small business self-employed, middle to large business selfemployed, and workers in standard employment across the years of 2006, 2010, and 2014.

were mainly involved in blue and pink collar job. The proportion of pink collar employment increased gradually over the years: $44.84 \%$ in $2006,52.95 \%$ in 2010 , and $59.08 \%$ in 2014.

Regarding the comparison of weekly work durations for self-employed individuals and workers in standard employment, the overall mean working time per week decreased in all workers over the years (Table 2). Self-employed persons were likely to work longer durations than workers in standard employment were, and small business owners had the longest weekly working time (60.00 hours in 2006, 58.50 hours in 2010, and 56.74 hours in 2014) of all workers. The percentage of overtime work declined continuously in standard employees during the study period. However, those self-employed in small businesses did not register a substantial reduction in weekly overtime working hours. The proportion of people who worked more than 52 hours weekly was the highest in those who were self-employed in small businesses $(61.06 \%$ in $2006,64.26 \%$ in 2010 , and $63.40 \%$ in 2014 ), followed by self-employed in middle to large enterprises $(34.57 \%$ in $2006,34.85 \%$ in 2010 , and $34.60 \%$ in 2014 ) and standard employment (28.11\% in 2006,
$24.09 \%$ in 2010 , and $17.46 \%$ in 2014). Likewise, the highest mean days of weekend work per month was also recorded for those who were self-employed in small businesses (4.92 days in 2006, 4.53 days in 2010, and 4.45 days in 2014), followed by people self-employed in middle to large organizations (3.47 days in 2006, 3.39 days in 2010, and 3.25 days in 2014) and finally those in standard employment (2.88 days in 2006, 2.36 days in 2010, and 1.84 days in 2014). The proportion of working while sick ("presenteeism") across the three groups was also the highest in self-employed small business owners: $23.91 \%$ in 2010 and $30.77 \%$ in 2014 .

The proportion of workers who successfully combined their work and other aspects of their life found the highest representation in those who were engaged in standard employment $(76.53 \%$ in $2006,75.47 \%$ in 2010 , and $75.94 \%$ in 2014) vis-à-vis the self-employed in small businesses and in middle to large enterprises (Figure 3). The proportion of work-life imbalance was particularly higher in small business owners in comparison to the other two groups: $40.43 \%$ in 2006, 38.4\% in 2010, and 40.8\% in 2014. 
Table 1. Distribution of socioeconomic characteristics for socioeconomic small business self-employed, middle to large business self-employed, and workers in standard employment across the years of 2006, 2010, and 2014

\begin{tabular}{|c|c|c|c|c|c|c|c|c|c|c|c|c|}
\hline & \multicolumn{3}{|c|}{2006} & & \multicolumn{3}{|c|}{2010} & \multicolumn{4}{|c|}{2014} & \multirow[b]{3}{*}{$P$-value } \\
\hline & \multicolumn{2}{|c|}{ Self-employed } & \multirow[b]{2}{*}{$\begin{array}{l}\text { Workers in } \\
\text { standard } \\
\text { employment }\end{array}$} & \multirow[b]{2}{*}{$P$-value } & \multicolumn{2}{|c|}{ Self-employed } & \multirow[b]{2}{*}{$\begin{array}{l}\text { Workers in } \\
\text { standard } \\
\text { employment }\end{array}$} & \multirow{2}{*}{$P$-value } & \multicolumn{2}{|c|}{ Self-employed } & \multirow[b]{2}{*}{$\begin{array}{l}\text { Workers in } \\
\text { standard } \\
\text { employment }\end{array}$} & \\
\hline & $\begin{array}{c}\text { Small } \\
\text { business }\end{array}$ & $\begin{array}{l}\text { Middle to } \\
\text { large } \\
\text { business }\end{array}$ & & & $\begin{array}{c}\text { Small } \\
\text { business }\end{array}$ & $\begin{array}{l}\text { Middle to } \\
\text { large } \\
\text { business }\end{array}$ & & & $\begin{array}{c}\text { Small } \\
\text { business }\end{array}$ & $\begin{array}{l}\text { Middle to } \\
\text { large } \\
\text { business }\end{array}$ & & \\
\hline \multicolumn{13}{|c|}{ Monthly income (US\$), n (\%): } \\
\hline$<$ US $\$ 1000$ & $\begin{array}{c}450 \\
(21.58)\end{array}$ & $13(5.35)$ & 748 (14.7) & $<0.0001$ & $\begin{array}{c}250 \\
(11.88)\end{array}$ & $1(0.76)$ & $425(9.7)$ & $<0.0001$ & $391(4.68)$ & $2(0.34)$ & $581(3.09)$ & $<0.0001$ \\
\hline $\begin{array}{l}\text { US\$1000-US\$ } \\
1999\end{array}$ & $832(39.9)$ & $19(7.82)$ & $2201(43.26)$ & & $\begin{array}{c}627 \\
(29.8)\end{array}$ & $6(4.55)$ & $1688(38.51)$ & & $\begin{array}{c}2118 \\
(25.37)\end{array}$ & $21(3.61)$ & $6186(32.89)$ & \\
\hline US\$2000-2999 & $\begin{array}{c}512 \\
(24.56)\end{array}$ & $74(30.45)$ & $1369(26.91)$ & & $\begin{array}{c}659 \\
(31.32)\end{array}$ & $15(11.36)$ & $1269(28.95)$ & & $\begin{array}{c}2699 \\
(32.32)\end{array}$ & 60 (10.33) & 6389 (32.89) & \\
\hline$\geq$ US\$3000 & $\begin{array}{c}291 \\
(13.96)\end{array}$ & $137(56.38)$ & $770(15.13)$ & & $568(27)$ & $110(83.33)$ & $1001(22.84)$ & & $3142(37.63)$ & 498(85.71) & $5653(30.05)$ & \\
\hline \multicolumn{13}{|c|}{ Education attainment, $n$ (\%): } \\
\hline Elementary or less & $160(7.67)$ & $4(1.65)$ & $142(2.79)$ & $<0.0001$ & $\begin{array}{c}110 \\
(5.23)\end{array}$ & $1(0.76)$ & $85(1.94)$ & $<0.0001$ & $111(1.33)$ & $0(0)$ & $110(0.58)$ & $<0.0001$ \\
\hline $\begin{array}{l}\text { Middle to high } \\
\text { school }\end{array}$ & $\begin{array}{c}1366 \\
(65.52)\end{array}$ & $85(34.98)$ & $2364(46.46)$ & & $\begin{array}{c}1370 \\
(65.11)\end{array}$ & $44(33.33)$ & $1987(45.33)$ & & $\begin{array}{c}5333 \\
(63.87)\end{array}$ & $161(27.71)$ & $6887(36.62)$ & \\
\hline College or more & $\begin{array}{c}559 \\
(26.81)\end{array}$ & $154(63.37)$ & $2582(50.75)$ & & $\begin{array}{c}624 \\
(29.66)\end{array}$ & 87 (65.91) & $2311(52.73)$ & & $\begin{array}{c}2906 \\
(34.80)\end{array}$ & $420(72.29)$ & $11812(62.80)$ & \\
\hline \multicolumn{13}{|c|}{ Job classification, $n$ (\%):* } \\
\hline White collar & $\begin{array}{c}337 \\
(16.16)\end{array}$ & $144(59.26)$ & $2546(50.04)$ & $<0.0001$ & $\begin{array}{c}385 \\
(18.3)\end{array}$ & $87(65.91)$ & $2195(50.08)$ & $<0.0001$ & $\begin{array}{c}1223 \\
(14.65)\end{array}$ & $317(54.56)$ & $10178(54.11)$ & $<0.0001$ \\
\hline Blue collar & $\begin{array}{c}813 \\
(38.99)\end{array}$ & $50(20.58)$ & $1740(34.2)$ & & $\begin{array}{c}605 \\
(28.75)\end{array}$ & $20(15.15)$ & $1221(27.86)$ & & $\begin{array}{c}2194 \\
(26.28)\end{array}$ & $110(18.93)$ & $4831(25.72)$ & \\
\hline Pink collar & $935(44.84)$ & $49(20.16)$ & $802(15.76)$ & & $\begin{array}{c}1114 \\
(52.95)\end{array}$ & $25(18.94)$ & $967(22.06)$ & & $\begin{array}{c}4933 \\
(59.08)\end{array}$ & $154(26.51)$ & $3793(20.17)$ & \\
\hline
\end{tabular}

"White collar: senior manager, professional/technical expertise, clerks; Blue collar: craft and related trades workers, equipment/machine operating and assembling workers; Pink collar: service and sales workers. 
Table 2. Distribution of work-related characteristics for small business self-employed, middle to large business self-employed, and workers in standard employment across the years of 2006, 2010, and 2014

\begin{tabular}{|c|c|c|c|c|c|c|c|c|c|c|c|}
\hline \multicolumn{3}{|c|}{2006} & \multirow[b]{3}{*}{$P$-value } & \multicolumn{3}{|c|}{2010} & \multirow[b]{3}{*}{$P$-value } & \multicolumn{3}{|c|}{2014} & \multirow[b]{3}{*}{$P$-value } \\
\hline \multicolumn{2}{|c|}{ Self-employed } & \multirow[b]{2}{*}{$\begin{array}{l}\text { Workers in } \\
\text { standard } \\
\text { employment }\end{array}$} & & \multicolumn{2}{|c|}{ Self-employed } & \multirow[b]{2}{*}{$\begin{array}{l}\text { Workers in } \\
\text { standard } \\
\text { employment }\end{array}$} & & \multicolumn{2}{|c|}{ Self-employed } & \multirow[b]{2}{*}{$\begin{array}{l}\text { Workers in } \\
\text { standard } \\
\text { employment }\end{array}$} & \\
\hline $\begin{array}{c}\text { Small } \\
\text { business }\end{array}$ & $\begin{array}{l}\text { Middle to } \\
\text { large } \\
\text { business }\end{array}$ & & & $\begin{array}{c}\text { Small } \\
\text { business }\end{array}$ & $\begin{array}{l}\text { Middle to } \\
\text { large } \\
\text { business }\end{array}$ & & & $\begin{array}{c}\text { Small } \\
\text { business }\end{array}$ & $\begin{array}{l}\text { Middle to } \\
\text { large } \\
\text { business }\end{array}$ & & \\
\hline \multicolumn{12}{|c|}{ Working time per week, mean (SE) } \\
\hline $\begin{array}{l}60 \\
(22.28)\end{array}$ & $\begin{array}{c}50.85 \\
(15.16)\end{array}$ & $48.3(12.48)$ & $<0.0001$ & $\begin{array}{c}58.5 \\
(19.33)\end{array}$ & $\begin{array}{c}51.2 \\
(13.17)\end{array}$ & $47.05(11.05)$ & $<0.0001$ & $\begin{array}{c}56.74 \\
(15.89)\end{array}$ & $\begin{array}{c}50.26 \\
(12.59)\end{array}$ & $45.39(9.47)$ & $<0.0001$ \\
\hline \multicolumn{12}{|c|}{ Over time working ( $\geq 52$ hours per week), number (\%) } \\
\hline $\begin{array}{l}1273 \\
(61.06)\end{array}$ & $84(34.57)$ & $1430(28.11)$ & $<0.0001$ & $\begin{array}{c}1352 \\
(64.26)\end{array}$ & $46(34.85)$ & $1056(24.09)$ & $<0.0001$ & $\begin{array}{c}5294 \\
(63.40)\end{array}$ & $\begin{array}{c}201 \\
(34.60)\end{array}$ & $3284(17.46)$ & $<0.0001$ \\
\hline \multicolumn{12}{|c|}{ Work on weekend per month, mean (SE): } \\
\hline $4.92(2.7)$ & $3.47(2.56)$ & $2.88(2.46)$ & $<0.0001$ & $4.53(2.69)$ & $3.39(2.84)^{\circ}$ & $2.36(2.44)$ & $<0.0001$ & $4.45(2.51)$ & $3.25(2.79)$ & $1.84(2.33)$ & $<0.0001$ \\
\hline \multicolumn{12}{|c|}{ Presenteeism, n (\%): } \\
\hline- & - & - & & $\begin{array}{c}503 \\
(23.91)\end{array}$ & $21(15.91)$ & $807(18.41)$ & $<0.0001$ & $\begin{array}{c}2569 \\
(30.77)\end{array}$ & $\begin{array}{c}136 \\
(23.41)\end{array}$ & $4532(24.09)$ & $<0.0001$ \\
\hline
\end{tabular}

SE - standard error 


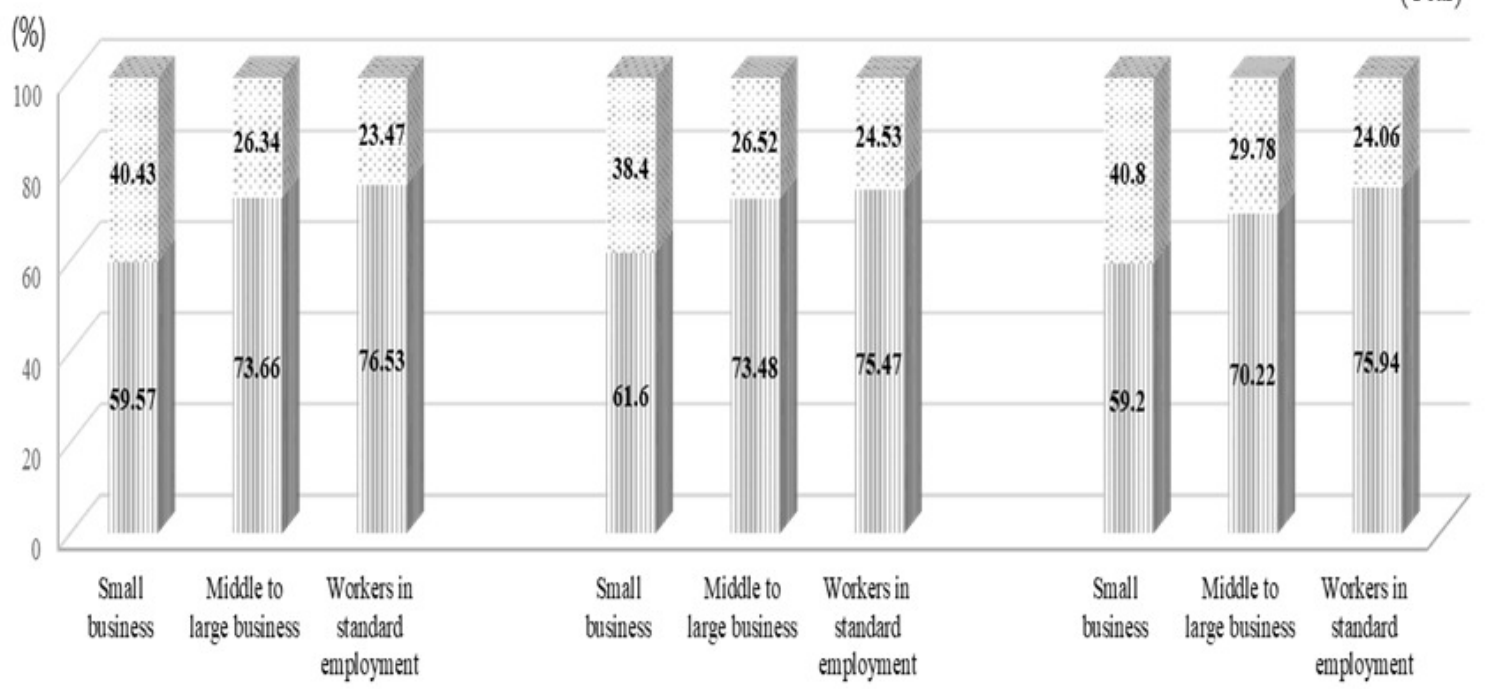

Figure 3. Distribution of work life balance and imbalance for small business self-employed, middle to large business self-employed, and workers in standard employment across the years of 2006, 2010, and 2014.

\section{DISCUSSION}

We found a clear distinction in socio-demographic and work-related attributes between self-employed workers and personnel in standard employment. In comparison to middle to large business owners or workers in standard employment, small business owners were more likely to hold a lower socioeconomic position and to experience undesirable working conditions, including longer, weekly work durations, weekend work, "presenteeism", and work-life imbalance. It is noteworthy that the observed differences among the groups prevailed through the years the survey was conducted.

The global proportion of self-employment (\% of total employment) has declined slightly but the figure is still substantial, averaging $14.3 \%-52.6 \%$ in 2017 based on the level of national income. ${ }^{12}$ In South Korea, self-employed workers comprise a large percentage of $29.4 \%$, which is almost twice as high as that of the world's high-income nations (14.3\%) and the fourth-highest among the 35 OECD member countries. ${ }^{13}$ The KWCS data also evidenced that substantial measure of the self-employed, recording $32.7 \%$ in 2006, 36.2\% in 2010, and 32.7\% in 2014 and small business owners accounted for more than $90 \%$ of this self-employed sector through the study periods. The statistics pertaining to self-employment prove without doubt that self-employment activity experts a tangible impact on job creation, economic growth, and poverty reduction. Expectedly, to understand the inherent characteristics of the self-employed individuals, small business owners are the key group to study as they are by far the largest component of self-employment.
Demographic and socioeconomic characteristics are vital indicators of economic differences in society and they help to predict the health and well-being of an individual. The differences in these features in the labor market reflect and reinforce the social inequality of workers. ${ }^{14,15}$ For example, socioeconomically disadvantaged workers were more at risk of negative outcomes across their life spans than their counterparts. ${ }^{16,17}$ The current study demonstrated that disparities in demographic and socioeconomic factors existed between self-employed individuals and workers in standard employment. In particular, small business owners with 0-4 employees were more likely to be older and male, earn lower levels of monthly income, attain lesser levels of education, and were engaged in manual and service positions than workers in standard employment. The nature of self-employment is heterogeneous; however, the self-employed were generally found to be male and older in terms of age. ${ }^{18,19}$ It is possible that older people are more likely to be self-employed than the youth are because they are in a better position to start a business, because of their experience and greater human and financial capitals. ${ }^{20}$ Self-employment may also be an inevitable option against layoffs or early retirement or it may be undertaken to delay retirement. ${ }^{20}$ The statistics of many countries commonly attest to the fact that earnings of self-employed individuals were lower or more volatile than those of waged employees. ${ }^{20-23}$ Given the relatively low and irregular income of the selfemployed, ${ }^{20-23}$ such people were likely to face more challenges regarding economic vulnerability and to encounter more financial problems than their employee counterparts. On the other hand, educational achievement and types of self-employment were quite discrete across nations. A higher proportion of the self-employed in some countries 
(ie, Germany, France, and US) was engaged in professional occupations which typically require specialized education and skills. ${ }^{20-23}$ The opposite was observed in other countries (ie, UK, Spain, and Japan), where the self-employed were less likely to be as educated as the other types of employees. $^{20,21}$ In Asian nations, self-employed persons were predominantly observed to have lower educational qualifications and to be engaged in unskilled or semi-skilled manual jobs. The KWCS data is consistent with this observation and it further highlights that individuals self-employed in small business were most vulnerable to low socioeconomic positions based on income, education, and occupation in comparison to middle to large business owners and workers in standard employment. This unequal distribution was observed throughout the study period, and this, seems to prevail. Given that inequality in socioeconomic positions could be present a decisive factor of inequality in health and social inequalities, ${ }^{14-17}$ future discussion beyond the scope of the present study is needed to support these findings.

Decent work is a broad concept that encompasses many dimensions. Appropriate work durations and work-life balance are important contributors in achieving this SDG. Selfemployed persons have been deemed to have failed in attaining decent work. Although the self-employed, as business owners, have high levels of autonomy, job control, and can create flexible schedules, their benefits often become double-edged swords. ${ }^{4,5}$ Since self-employed persons are responsible for absolutely everything related to their own businesses, they become liable to exploitation at the workplace: they are more likely to work longer hours and to face difficulties in harmonizing their work and family life than waged employees. ${ }^{5,8,24}$ The findings of the present investigation corroborate this outcome. Compared to employed workers, self-employed persons in both small businesses and in middle to large enterprises worked longer weekday hours and also worked more often on the weekends. The proportion of people working more than 52hours per week (defined as legal working hours in South Korea) was much higher for self-employed persons than for workers in standard employment. Small business owners seemed to evidence the most accurate cases of working overtime and registered the longest working hours and the most number of working days vis-à-vis any other employment type compared through the current analysis. The self-employed were also more likely to work even when they were sick. Similar results were reported by Kim et al. (2014), who found that self-accounting workers displayed $27 \%$ higher odds in exhibiting "presenteeism" than paid workers. ${ }^{25}$ The authors reasoned that the self-employed need to be working even when they do not feel well because they cannot allocate other people to substitute for them when they are sick. $^{25}$ The results of the present analysis could be also similarly understood: small business owners are willing to accept undesirable working conditions such as "presenteeism" because they are ultimately responsible for the entire business.

Reconciling work and life might become difficult for the self-employed in light of their increased responsibilities in the workplace, their inordinately long weekday working hours, and their propensity for weekend work. A lower rate of work-life balance was observed in self-employed indi- viduals in comparison to those in standard employment, and small business owners were particularly susceptible to imbalances between work and other aspects of their lives. This result was fairly consistent through the study years of 2006, 2010, and 2014. Self-employment often accords flexible working schedules and high job control. Paradoxically, the unexpected demands of family life can make these advantages causes for conflict because of the self-employed alone carry the entire burden of the responsibility for the business and the pressure of its success or failure. This selfaccounted onus leads to work-life disharmony, as attested by studies that have reported high incidences of work and life conflict and imbalance among the self-employed. ${ }^{26-28}$ However, there are obvious contradictions about the inequity between work and life of self-employed individuals. Existing studies have demonstrated that the positive aspects of high flexibility and control at work enhanced the reconciliation of work and private life matters for the selfemployed. ${ }^{29,30}$ Ascertaining whether the self-employed negotiate a better work-life balance than waged employees can be tricky. Further research is required to clarify this issue and to elucidate the major factors that may contribute to disharmonies between work and other aspects of person's life.

Our findings need to be interpreted carefully. Although the current study described the characteristics of the selfemployed across the years of 2006, 2010, and 2014, it was based on cross-sectional approach wherein the data were combined over a period of time and achieved the same analysis in each period. Therefore, this study do not support time trend of the characteristics and sort of differentiation over the years. The results have limitations derived from the cross-sectional study. Thus, determining causality is challenging; for example, small businesses were more likely to have socioeconomic disadvantages, or socially disadvantaged persons were more likely to be small business owners. Therefore, the cross-sectional data could be incomplete, and selection bias or measurement error may occur when recruiting participants or collecting information. However, because the KWCS is a national survey with representative sample, rigid sampling procedure, and the questionnaire, we believe that quality assurance of the data and results are less likely biased toward the meaningless and absurd.

\section{CONCLUSIONS}

In conclusion, the present descriptive investigation showed that self-employed individuals, especially those heading small businesses, were more likely to be exposed to socioeconomic disadvantages and to the worst working conditions than standard waged workers. Their vulnerability seems to be quite persistent, and has prevailed at least through the duration of the study that was undertaken between 2006 and 2014. Given the shifting values and attitudes and the uncertainties of global economy, self-employment functions in major capacities in the economic development and job growth of a nation and it accounts for a large part of the working population of the world. Nevertheless, as informal sector employees, self-employment individuals are considered to be outside the purview of the regular labor market. Increasing their poor quality job held by societal and work- 
ing environments is likely to exacerbate inequalities concerning occupational safety and health. Bearing in mind the global agenda and the SDG achieving the eradication of social and health inequalities in the working population, practical strategies are needed to foster social services, public assistance, and labor protection, and to reduce health inequalities for the self-employed. Small business owners may have to be given priority.

\section{CORRESPONDENCE TO:}

Kyoung-Bok Min

Department of Preventive Medicine

Seoul National University College of Medicine

103 Daehak-ro

Jongno-gu

Seoul 110-799

Republic of Korea

minkb@snu.ac.kr 


\section{REFERENCES}

1. European Commission. Non-Standard Employment and Access to Social Security Benefits. Brussels; 2015.

\section{International Labour Organization. Non-Standard Employment Around the World: Understanding Challenges, Shaping Prospects. ILO; 2016.}

3. World Health Organization. High-Level Commission on Health Employment and Economic Growth. Working for Health and Growth: Investing in the Health Workforce. World Health Organization; 2016.

4. Dawson CJ, Henley A, Latreille PL. Why Do Individuals Choose Self-Employment? Why do individuals choose self-employment? IZA discussion paper no. 3974; 2009.

5. Andersson P. Happiness and health: Well-being among the self-employed. J Socio-Economics. 2008;37:213-236. doi:10.1016/i.socec.2007.03.003

6. Williams C, Lapeyre F. Dependent Self-Employment: Trends, Challenges and Policy Responses in the EU. ILO; 2017.

7. Millán JM, Hessels J, Thurik R, Aguado R. Determinants of job satisfaction: a European comparison of self-employed and paid employees. Small Bus Econ. 2013;40(3):651-670. doi:10.1007/s111 87-011-9380-1

8. Prottas DJ, Thompson CA. Stress, satisfaction, and the work-family interface: a comparison of selfemployed business owners, independents, and organizational employees. J Occup Health Psychol. 2006;11(4):366-378. doi:10.1037/1076-8998.11.4.366

9. Ekelund J, Johansson E, Järvelin MR, Lichtermann D. Self-employment and risk aversion? evidence from psychological test data. Labour Econ. 2005;12(5):649-659. doi:10.1016/j.labeco.2004.02.009

10. Eurofound. Working Time and Work-Life Balance in a Life Course Perspective. Eurofound; 2012.

11. Park J, Lee N. First Korean Working Conditions Survey: a comparison between South Korea and EU countries. Ind Health. 2009;47:50-54. doi:10.2486/ind health.47.50

12. World Bank. World Bank Data. Published online 2018. Accessed April 14, 2019. https://data.worldban k.org/indicator/SL.EMP.SELF.ZS
13. Organisation for Economic Co-operation and Development. Self-employment rate (indicator). Published online 2018. Accessed May 16, 2019. http s://data.oecd.org/emp/self-employment-rate.htm

14. Min JY, Park SG, Hwang SH, Min KB. Disparities in precarious workers' health care access in South Korea. Am J Ind Med. 2016;59(12):1136-1144. doi:10.1002/aji $\underline{\text { m.22658 }}$

15. Quinlan M. The Effects of Non-Standard Forms of Employment on Worker Health and Safety. International Labor Organization; 2015.

16. Min KB, Park SG, Hwang SH, Min JY. Precarious employment and the risk of suicidal ideation and suicide attempts. Prev Med. 2015;71:72-76. doi:10.101 6/j.ypmed.2014.12.017

17. Min KB, Park SG, Song JS, Yi KH, Jang TW, Min JY. Subcontractors and increased risk for work-related diseases and absenteeism. Am J Ind Med. 2013;56:1296-1306. doi:10.1002/ajim.22219

18. Katz LF, Krueger AB. The Rise and Nature of Alternative Work Arrangements in the United States, 1995-2015. National Bureau of Economic Research; 2016. doi:10.3386/w22667

19. Manser ME, Garnett P. Self-Employment in Canada and the United States. Accessed May 16, 2019. http://citeseerx.ist.psu.edu/viewdoc/download?doi=1 $\underline{0.1} 1.550 .1668 \&$ rep $=$ rep $1 \&$ type $=$ pdf

20. Hatfield I. Self-Employment in Europe. Institute for Public Policy Research; 2015.

21. Diamond J, Schaede U. Self-employment in Japan. A microanalysis of personal profiles. Soc Sci Jpn J. 2013;16:1-28. doi:10.1093/ssii/iys023

22. Hipple SF, Hammond LA. BLS spotlight on statistics: Self-employment In The United States. Accessed May 16, 2019. https://digitalcommons.ilr.cor nell.edu/cgi/viewcontent.cgi?referer=https://www.go ogle.com/\&httpsredir $=1$ \&article $=2788$ \& context=ke y_workplace

23. Miao C. Self-Employment and Happiness in China. Department of Economics and Statistics. Linnaeus University. SE-351 95 Vaxjo. Sweden; 2015:16.

24. Hagqvist E, Toivanen S, Vinberg S. Time strain among employed and self-employed women and men in Sweden. Society, Health \& Vulnerability. 2015;6:29183. doi:10.3402/shv.v6.29183 
25. Kim MS, Park JB, Min KB, Lee KJ, Kwon K. Presenteeism among self-employed workers: Korean working conditions survey. Ann Occup Environ Med. 2014;26:32. doi:10.1186/s40557-014-0032-1

26. Chung H. Work-family conflict across 28 European countries: A multi-level approach. In: Drobnic S, Guillén AM, eds. Work-Life Balance in Europe. The Role of Job Quality. Palgrave Macmillan UK; 2011:42-68. do i: $10.1057 / 97802303075823$

27. Fagan C, Walthery P. Job quality and the perceived work-life balance fit between work hours and personal commitments: A comparison of parents and older workers in Europe. In: Drobnic S, Guillén AM, eds. Work-Life Balance in Europe. The Role of Job Quality. Palgrave Macmillan UK; 2011:69-94. doi:10.1057/978 $\underline{02303075824}$
28. Nordenmark M, Vinberg S, Strandh M. Job control and demands, work-life balance and wellbeing among self-employed men and women in Europe. Vulnerable Groups Inclusion. 2012;3:18896. doi:10.3402/vgi.v3i $\underline{0.18896}$

29. Eddleston KA, Powell GN. Nurturing Entrepreneurs' Work-Family Balance: A Gendered Perspective. Entrep Theory Pract. 2012;36(3):513-541. doi:10.1111/j.1540-6520.2012.00506.x

30. Hilbrecht M, Lero DS. Self-employment and family life: constructing work-life balance when you're 'always on.' Community Work Fam. 2014;17(1):20-42. doi:10.1080/13668803.2013.862214 